\title{
STUDI STABILITAS DINDING PENAHAN TANAH KANTILEVER PADA RUAS JALAN SILAING PADANG - BUKITTINGGI KM 64+500
}

\author{
Abdul Hakam ${ }^{1}$, Rizki Pranata Mulya ${ }^{2}$
}

\begin{abstract}
ABSTRAK
Hujan deras yang terjadi pada tanggal 30 Maret 2010 yang lalu mengakibatkan dinding penahan tanah kantilever pada ruas jalan Silaing, Padang Bukittingi Km 64+500 mengalami guling. Selain itu, gempa yang sering terjadi di daerah Sumatera Barat khususnya, menyebabkan tanah di belakang dinding penahan tanah kehilangan daya dukungnya. Stabilitas dinding penahan tanah dapat dinyatakan dengan nilai Fs (faktor keamanan). Nilai faktor keamanan yang ditinjau adalah Fs Overtuning yaitu faktor keamanan terhadap gaya guling, Fs Slading adalah faktor keamanan terhadap geser pada dasar dinding penahan tanah, Fs bearing capacity adalah faktor keamanan terhadap keruntuhan daya dukung. Tujuan dari studi ini adalah untuk menganalisa stabilitas dinding kantilever dan untuk mengetahui penyebab ketidak stabilan dinding kantilever tersebut dan mendisain dimensi baru yang aman terhadap beban statis dan dinamis. Hasil dari studi ini menunjukkan bahwa dinding kantilever yang terpasang tersebut, dengan dimensi $\mathrm{H}=8,5, \mathrm{~B}=3$, $\mathrm{Ta}=0,5, \mathrm{~Tb}=0,7 \mathrm{Tt}=0,7, \mathrm{Th}=0,4$ tidak aman karena nilai stabilitasnya tidak sesuai dengan yang disyaratkan, yaitu sebesar Fs guling=1,577, Fs Geser=1,384, Fs daya dukung tidak dicari karena nilai e lebih kecil dari $\mathrm{B} / 6$. Dengan memperbesar dimensi, $\mathrm{H}=9,5, \mathrm{~B}=5, \mathrm{Ta}=0,5, \mathrm{~Tb}=0,95 \mathrm{Tt}=0,95$, $\mathrm{Th}=0,95, \mathrm{D}=1,1$ dinding kantilever tersebut dinyatakan aman dengan nilai faktor kemanan sebesar Fs guling=3,547, Fs Geser=2,559, Fs daya dukung=15,094.
\end{abstract}

Kata Kunci : stabilitas, dinding kantilever, dimensi

\section{PENDAHULUAN}

Hujan deras yang melanda Sumatera Barat khususnya daerah Silaing pada tanggal 30 Maret 2010 yang lalu mengakibatkan banyaknya terjadi bencana longsor pada daerah tersebut. Selain diakibatkan oleh hujan deras, bencana alam gempa yang akhir-akhir ini sering melanda Sumatera Barat, khususnya gempa pada tanggal 30 September 2009 juga menjadi salah satu penyebab longsor ini. Kerusakan struktur tanah akibat langsung dari gempa adalah menurunnya daya dukung tanah. Selain itu gempa juga mengakibatkan kerengkahan pada tanah yang apabila kadar air tanah tersebut meningkat, akan sangat mudah mengalami kelongsoran.

Tujuan dari studi ini adalah untuk menganalisa stabilitas dinding kantilever dan untuk mengetahui penyebab ketidakstabilan dinding kantilever tersebut akibat beban statis dan dinamis, dan merencanakan dinding kantilever yang baru dengan memperbesar dimensi. Manfaat dari studi ini adalah hasil penelitian ini dapat dijadikan sebagai rekomendasi bagi pihak terkait (Dinas Pekerjaan Umum) dalam merencanakan dinding penahan tanah pada daerah tersebut.

\section{DASAR TEORI}

\subsection{Teori Analisa Stabilitas Lereng}

Tegangan geser tanah adalah gaya perlawanan yang dilakukan butir-butir tanah terhadap desakan atau tarikan. Dengan dasar pengertian ini, bila tanah mengalami pembebanan akan dilakukan oleh:

${ }^{1}$ Dosen Jurusan Teknik Sipil Fakultas Teknik Universitas Andalas, ahakam2008@yahoo.com

${ }^{2}$ Staf Teknis Pusat Studi Bencana Universitas Andalas, 
1. Kohesi tanah yang tergantung pada jenis tanah dan kepadatannya, tetapi tidak tergantung dari tegangan vertikal yang bekerja pada bidang gesernya.

2. Gesekan antara butir-butir tanah yang besarnya berbanding dengan tegangan vertikal pada bidang gesernya.

Bila gaya geser bekerja pada permukaan dimana bekerja pula tegangan normal, maka harga $\tau$ akan membesar akibat deformasi mencapai harga batas. Karakteristik kekuatan dari tanah yang dinyatakan oleh persamaan Coulomb.

$$
\tau=c+\sigma \tan \phi
$$

dimana:

$$
\begin{array}{ll}
\tau & =\text { Tegangan geser } \\
\mathrm{c} & =\text { Kohesi tanah } \\
\phi & =\text { Sudut geser tanah } \\
\sigma & =\text { Tegangan normal yang bekerja }
\end{array}
$$

\subsection{Dinding Penahan Tanah (Retaining Wall)}

Dinding penahan tanah merupakan salah satu konsep perkuatan tanah yang banyak digunakan dalam pekerjaan rekayasa sipil. Dinding penahan tanah merupakan dinding yang digunakan untuk menahan beban tanah secara vertikal ataupun terhadap kemiringan tertentu.

Dinding-dinding penahan adalah konstruksi yang digunakan untuk memberikan stabilitas tanah atau bahan lain yang kondisi massa bahannya tidak memiliki kemiringan alami, dan juga digunakan untuk menahan atau menopang timbunan tanah atau onggokan material lainnya (Bowles, 1999: 49)

Dalam perencanaan sebuah dinding penahan tanah, perlu diambil dimensi tertentu sehingga dinding yang direncanakan mungkin untuk dikerjakan, cukup stabil dan kuat. Pengambilan dimensi awal dinding penahan tanah juga sangat ditentukan dengan bentuk lereng dan tanah yang kan ditahannya. Selain itu pengambilan dimensi dari segi keterbatasan ruang pekerjaan, kepatutan bentuk dan juga keindahan harus diperhatikan dalam perencanaan dinding kantilever ini.

Sebagai pedoman awal dalam pengambilan dimensi dinding kantilever pada Gambar 1 ditampilkan potongan penampang dinding kantilever. Puncak badan dinding penahan tanah tidak boleh kurang dari $0,3 \mathrm{~m}$ untuk penempatan yang layak dari beton dapat dilakukan. Dasar badan setidak-tidaknya harus cukup tebal untuk memenuhi persyaratan geser. Kedalaman ke dasar plat D, harus memenuhi nilai minimum sebesar 0,6 m. Bagaimanapun, bagian dasar dari plat harus berada dibawah kedalaman beku dan perubahan volume musiman.

Dimensi dasar plat harus sedemikian rupa sehingga resultan beban-beban vertikal jatuh dalam sepertiga bagian tengahan. Jika resultan jatuh diluar sepertiga bagian tengahan, maka tekanan tapak akan berlebihan dan hanya sebagian dari telapak yang efektif.

\subsection{Stabilitas Dinding Penahan Tanah}

Untuk mengetahui stabilitas dinding penahan tanah kantilever, perlu dilakukan pengecekan terhadap dinding kantilever tersebut. Pengecekan tersebut diantaranya:

- Cek Terhadap Guling

- Cek Terhadap Geser

- Cek Terhadap Keruntuhan Daya Dukung

\section{8 | J URNAL REKAYASA SIPIL}




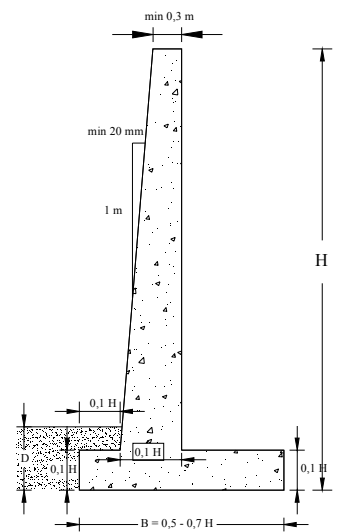

Gambar 1. Komposisi Ukuran Minimal Dinding Penahan Tanah Kantilever (Das,1990)

\subsection{Stabilitas Dinamis}

Analisis dinamis ekivalen untuk stabilitas dinding penahan tanah merupakan analisis pengaruh beban dinamis yang dapat diterapkan pada dinding penahan tanah. Metoda ini dilakukan dengan memberikan gaya-gaya besar dan arahnya sesuai dengan beban yang diakibatkan percepatan gempa. Analisis ini mengasumsikan bahwa beban dinamis yang bekerja hanya memberi pengaruh pada nilai maksimumnya saja sepanjang riwayat waktu gempa.

Analisis stabilitas dinamis dinding penahan tanah dengan metoda dinamis ekivalen, bertujuan untuk membandingkan nilai gaya-gaya penahan dengan nilai gaya yang meruntuhkan dinding baik akibat gravitasi sekaligus akibat gempa. Gaya-gaya tersebut bekerja pada titik pusat massa dari elemen-elemen dinding penahan.

\section{PROSEDUR DAN HASIL KERJA}

\subsection{Survey Lapangan}

Survey lapangan dilakukan bertujuan untuk mendapatkan data yang sesuai dengan kondisi di lapangan. Survey (pengambilan data) dilakukan di jalan raya Padang-Bukittinggi, tepatnya di kawasan Silaing KM 64+500.

\subsubsection{Data Tanah}

Dalam mendisain dinding kantilever, data tanah yang harus diketahui adalah nilai berat volume $(\gamma)$, nilai kohesi (c), dan nilai sudut geser ( ). Data tersebut diambil pada dua titik yaitu untuk kondisi tanah pada dasar sungai dan untuk kondisi tanah timbunan yang berada di belakang dinding kantilever.

Dari pengujian tanah tersebut diperoleh data sebagai berikut:

1. Kondisi tanah timbunan di belakang dinding kantilever:

$$
\begin{aligned}
\gamma 1 & =15,65 \mathrm{kN} / \mathrm{m}^{3} \\
\mathrm{c}_{1} & =7 \mathrm{kN} / \mathrm{m}^{2} \\
1 & =37,16
\end{aligned}
$$

dari hasil analisa saringan jenis tanah pada dasar sungai digolongkan pada tanah pasir berkerikil bergradasi baik (Gambar 2.) 


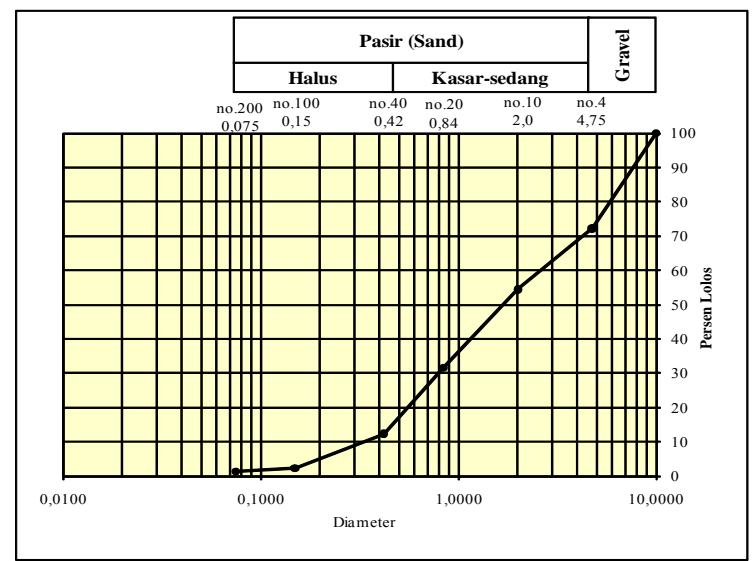

\section{Gambar 2. Grafik Analiasa Saringan Kondisi Tanah Asli}

2. Kondisi tanah pada dasar sungai:

$$
\begin{aligned}
\gamma_{2} & =17,91 \mathrm{kN} / \mathrm{m}^{3} \\
\mathrm{c}_{2} & =2,8 \mathrm{kN} / \mathrm{m}^{2} \\
2 & =42,38
\end{aligned}
$$

Dari hasil analisa saringan, jenis tanah pada dasar sungai digolongkan pada tanah pasir sesuai dengan hasil yang ditunjukkan pada Gambar 3.

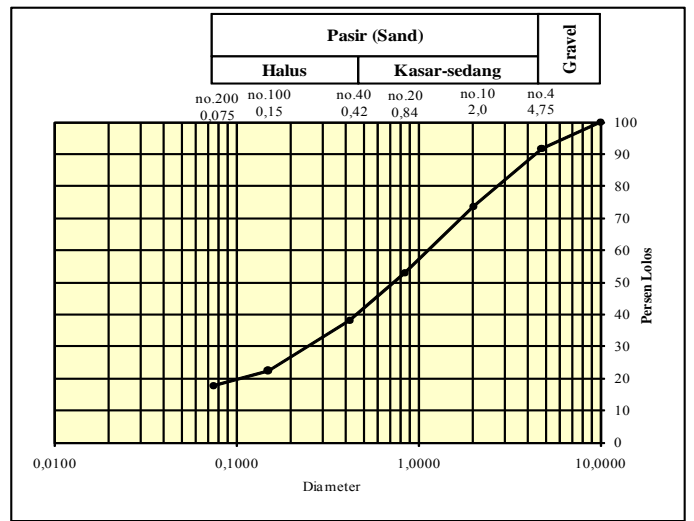

\section{Gambar 3. Grafik Analiasa Saringan Kondisi Tanah Timbunan}

\subsubsection{Dimensi Lapangan}

Untuk mendapatkan dimensi dinding kantilever sesuai dengan ukuran di lapangan dilakukan pengukuran dengan menggunakan meteran $50 \mathrm{~m}$. Pengukuran ini dilakukan terhadap dinding kantilever yang terguling.

Dari hasil pengukuran diperoleh dimensi dinding kantilever seperti Gambar 4. Jika dibandingkan dengan komposisi ukuran menurut Das, 1990: 289 yang terdapat pada Gambar 1, diperoleh perbandingan seperti yang terlihat pada Tabel 1.

Dari hasil perbandingan pada Tabel 1. dapat disimpulkan bahwa ukuran dinding penahan tanah yang terpasang di lapangan tidak memenuhi ukuran yang dianjurkan pada Das, 1991. 


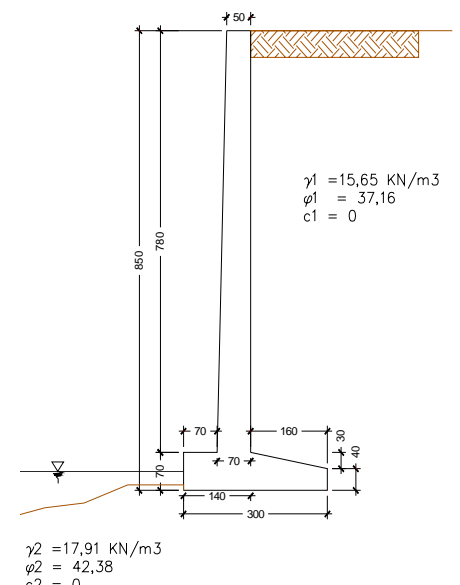

Gambar 4. Dimensi Lapangan

Tabel 1. Perbandingan Dimensi Menurut Das, 1990 Dengan Dimensi Lapangan

\begin{tabular}{|l|l|l|l|l|}
\hline & \multicolumn{1}{|c|}{ Das, 1990} & \multicolumn{2}{|c|}{ Lapangan } & Ket \\
\hline \hline $\mathrm{H}$ & H' & $8,5 \mathrm{~m}$ & - & \\
\hline $\mathrm{S}$ & $20 \mathrm{~mm}: 1 \mathrm{~m}$ & $25 \mathrm{~mm}: 1 \mathrm{~m}$ & & \\
\hline H toe & $0,1 \mathrm{H}$ & $0,7 \mathrm{~m}$ & $0,082 \mathrm{H}$ & Not oke \\
\hline H heel & $0,1 \mathrm{H}$ & $0,4 \mathrm{~m}$ & $0,047 \mathrm{H}$ & Not oke \\
\hline B & $0,5-0,7 \mathrm{H}$ & $3 \mathrm{~m}$ & $0,35 \mathrm{H}$ & Not oke \\
\hline
\end{tabular}

3.2 Perhitungan Stabilitas Dinding Penahan Tanah Kantilever dengan Dimensi Lapangan

\subsubsection{Dimensi Dinding Kantilever}

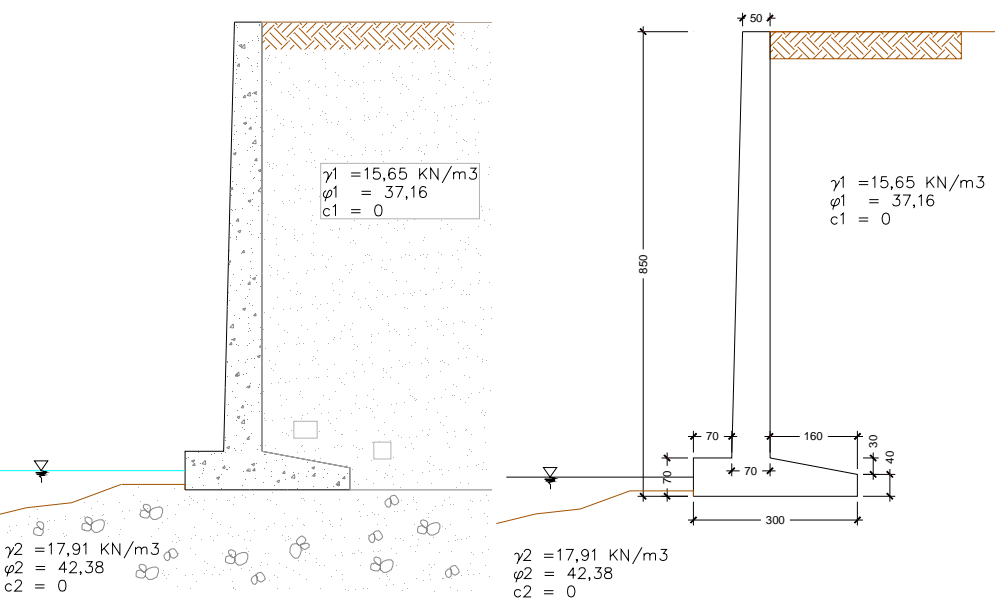

Gambar 5. Penampang dan Dimensi Dinding Kantilever

Dari Gambar 5. diperoleh:

$\mathrm{H}^{\prime}=8,5 \mathrm{~m}$

$\mathrm{B}=3 \mathrm{~m}$

$\mathrm{T}=50 \mathrm{~cm}$ 
Tinggi toe $=0,7 \mathrm{~m}$

Tinggi heel $=0,4 \mathrm{~m}$

Panjang toe $=0,7 \mathrm{~m}$

Panjang heel $=1,6 \mathrm{~m}$

$\mathrm{D}=0,1 \mathrm{~m}$

\subsubsection{Perhitungan Faktor Keamanan}

Beban beban yang bekerja pada dinding kantilever, dijabarkan pada Gambar 6. berikut:

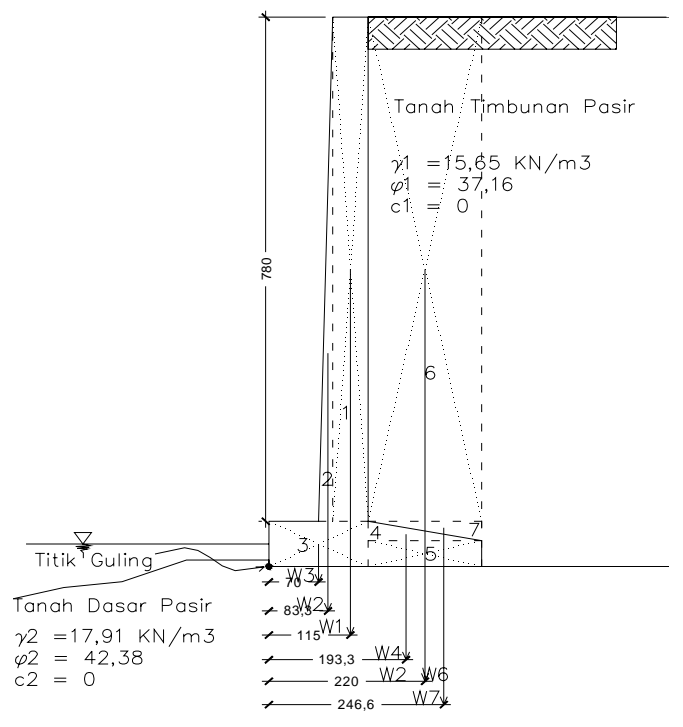

\section{Gambar 6. Beban-Beban yang Bekerja dan Lengan Momen Pada Dinding Kantilever Dimensi Lapangan}

- Momen guling yang bekerja, $\mathrm{M}_{0}$ (Tabel 2.)

Tabel 2. Gaya Vertikal dan Momen Tahanan yang Bekerja

\begin{tabular}{|c|c|c|c|c|}
\hline Segmen & $\begin{array}{l}\text { luas } \\
\left(\mathrm{m}^{2}\right)\end{array}$ & $\begin{array}{l}\text { Berat/ satuan panjang } \\
\qquad(\mathrm{KN})\end{array}$ & $\begin{array}{l}\text { Lengan momen } \\
\text { thdp titik } C(m)\end{array}$ & $\begin{array}{c}\text { Momen terhadap titik } \\
\mathrm{C}(\mathrm{KNm})\end{array}$ \\
\hline [1] & {$[2]$} & {$[3=2 \times y]$} & [4] & {$[5=3 \times 4]$} \\
\hline 1 & 3,9 & 93,6 & 1,15 & 107,64 \\
\hline 2 & 0,78 & 18,72 & 0,833 & 15,59376 \\
\hline 3 & 0,98 & 23,52 & 0,7 & 16,464 \\
\hline 4 & 0,24 & 5,76 & 1,933 & 11,13408 \\
\hline 5 & 0,64 & 15,36 & 2,2 & 33,792 \\
\hline 6 & 12,48 & 195,312 & 2,2 & 429,6864 \\
\hline 7 & 0,24 & 3,756 & 2,466 & 9,262296 \\
\hline & $\Sigma \mathrm{V}$ & 356,028 & $\Sigma \mathrm{M}_{\mathrm{R}}$ & 623,572536 \\
\hline
\end{tabular}

Resume dari nilai faktor keamanan pada dinding kantilever dimensi lapangan dapat dilihat pada Tabel 3, sementara gaya-gaya yang bekerja dapat dilihat pada Gambar 7.

\section{2 | JURNAL REKAYASA SIPIL}


Tabel 3. Resume Faktor Keamanan Pada Dinding Kantilever Dimensi Lapangan

\begin{tabular}{|c|c|c|}
\hline Fs Guling & 1,577 & $<2$, not oke \\
\hline Fs Geser & 1,384 & $<1,5$, not oke \\
\hline $\begin{array}{l}\text { Fs Daya } \\
\text { Dukung }\end{array}$ & $\begin{array}{l}e=\frac{B}{2}-\frac{\sum M_{r}-\sum M_{0}}{\Sigma V} \\
e=0.859\end{array}$ & $\begin{array}{l}\text { Untuk mencari nilai } \\
\text { Fs daya dukung, } \\
\text { nilai eksentrisitas } \\
(\mathrm{e})<\mathrm{B} / 6 \text {, dimana: } \\
\frac{B}{6}=0,5\end{array}$ \\
\hline
\end{tabular}

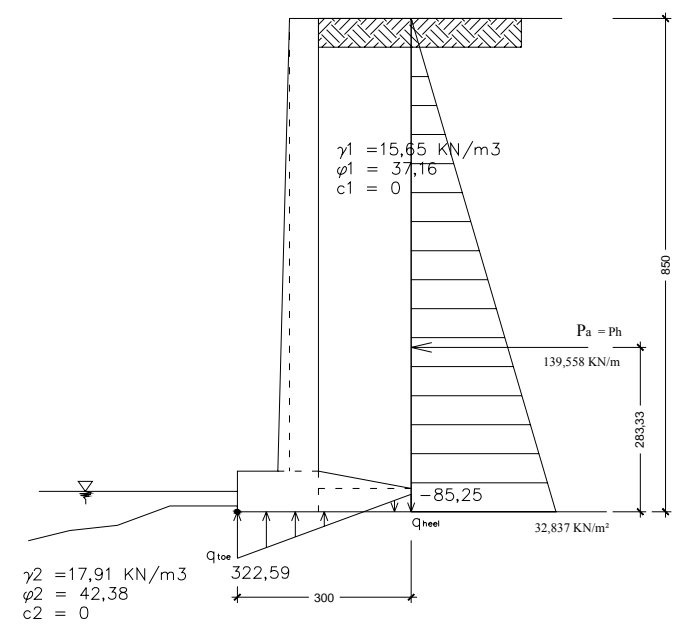

Gambar 7. Gaya-Gaya Yang Bekerja Pada Dinding Kantilever Dimensi Lapangan

\subsection{Perhitungan Stabilitas Dinding Penahan Tanah Kantilever dengan Dimensi Baru}

Perubahan dimensi (Gambar 8. dan Tabel 4.) dilakukan karena hasil yang diperoleh pada perhitungan sebelumnya tidak memenuhi ketentuan faktor keamanan.

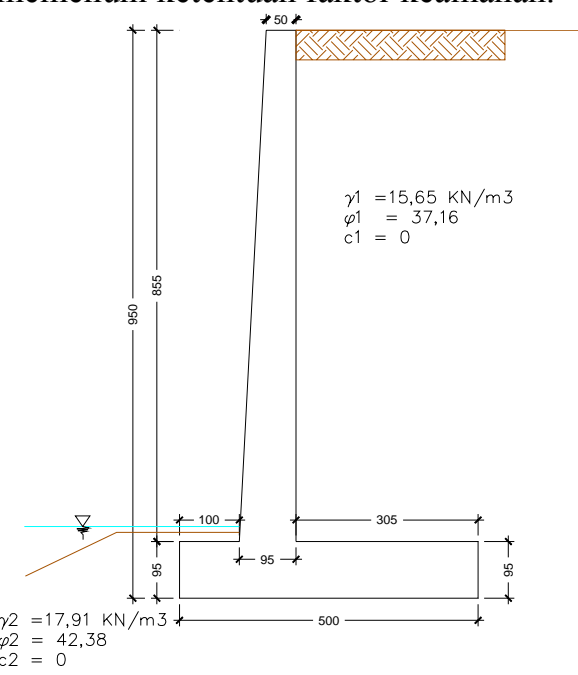

Gambar 8. Dimensi baru 
Tabel 4. Perbandingan Dimensi Menurut Das, 1990 Dengan Dimensi Baru

\begin{tabular}{|c|c|c|c|c|}
\hline & Das, 1990 & \multicolumn{2}{|c|}{ Dimensi Baru } & Ket \\
\hline \hline $\mathrm{H}$ & $\mathrm{H}^{\prime}$ & $9,5 \mathrm{~m}$ & - & \\
\hline s min & $20 \mathrm{~mm}: 1 \mathrm{~m}$ & $47 \mathrm{~mm}: 1 \mathrm{~m}$ & & oke \\
\hline H toe & $0,1 \mathrm{H}$ & $0,95 \mathrm{~m}$ & $0,1 \mathrm{H}$ & oke \\
\hline H heel & $0,1 \mathrm{H}$ & $0,95 \mathrm{~m}$ & $0,1 \mathrm{H}$ & oke \\
\hline B & $0,5-0,7 \mathrm{H}$ & $5 \mathrm{~m}$ & $0,53 \mathrm{H}$ & oke \\
\hline
\end{tabular}

\subsubsection{Dimensi Dinding Kantilever}

Untuk pembagian segmen dari bangunan tersebut dijabarkan dalam Gambar 9.

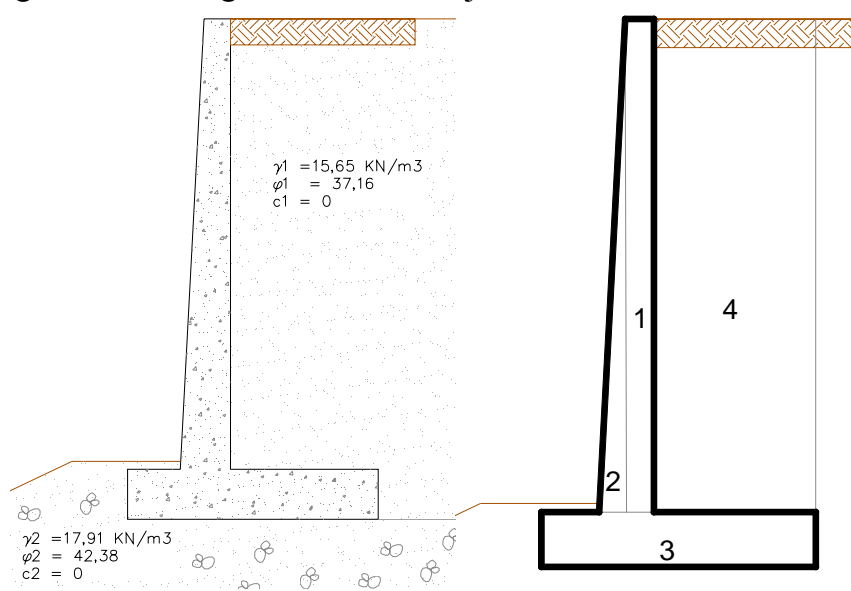

Gambar 9. Penampang dan Pembagian Segmen Dinding Kantilever

Dari Gambar 9. diperoleh:

$\mathrm{H}^{\prime}=9,5 \mathrm{~m}$

$\mathrm{T}=50 \mathrm{~cm}$

$\mathrm{B}=5 \mathrm{~m}$

Tinggi toe $=0,95 \mathrm{~m}$

Tinggi heel $=0,95 \mathrm{~m}$

Panjang toe $=1 \mathrm{~m}$

Panjang heel $=3,05 \mathrm{~m}$

$\mathrm{D}=1,1 \quad \mathrm{~m}$

\subsubsection{Perhitungan Faktor Keamanan}

Beban-beban yang bekerja pada dinding kantilever, dijabarkan pada Gambar 10. 


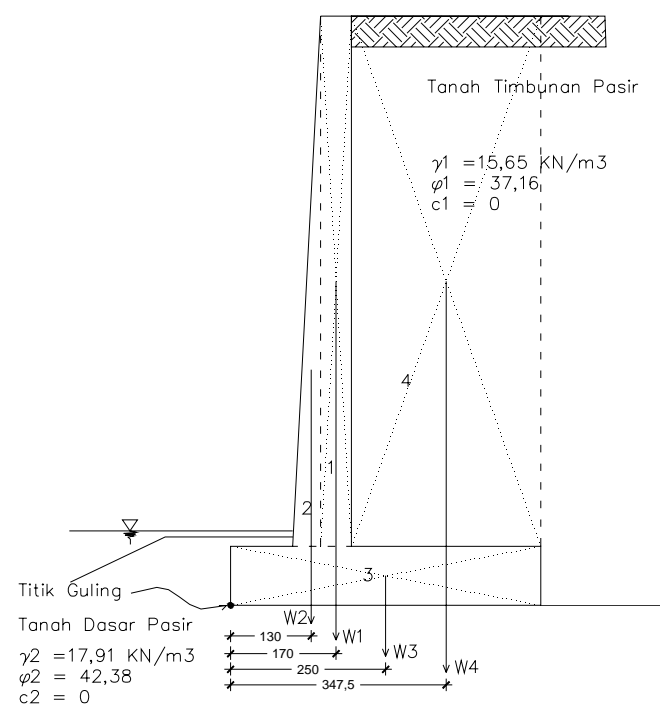

Gambar 10. Beban-Beban yang Bekerja dan Lengan Momen Pada Dinding Kantilever Dengan Dimensi Baru

- Momen guling yang bekerja, $\mathrm{M}_{0}$ (Tabel 5.)

$\bullet$

Tabel 5. Gaya Vertikal dan Momen Tahanan Yang Bekerja

\begin{tabular}{|c|c|c|c|c|}
\hline Segmen & $\begin{array}{l}\text { luas } \\
\left(\mathrm{m}^{2}\right)\end{array}$ & $\begin{array}{c}\text { Berat/ satuan panjang } \\
(\mathrm{KN})\end{array}$ & $\begin{array}{l}\text { Lengan momen } \\
\text { thdp titik } C(m)\end{array}$ & $\begin{array}{c}\text { Momen terhadap titik } \\
\qquad \mathrm{C}(\mathrm{KNm})\end{array}$ \\
\hline [1] & [2] & {$[3=2 \times y]$} & [4] & {$[5=3 \times 4]$} \\
\hline 1 & 4,275 & 102,6 & 1,7 & 174,42 \\
\hline 2 & 1,92375 & 46,17 & 1,3 & 60,021 \\
\hline 3 & 4,75 & 114 & 2,5 & 285 \\
\hline 4 & 26,0775 & 408,112875 & 3,475 & 1418,192241 \\
\hline \multirow[t]{2}{*}{5} & $P p$ & 55,649 & 0,3667 & 20,4064883 \\
\hline & $\Sigma \mathrm{V}$ & 726,531875 & $\Sigma \mathrm{M}_{\mathrm{R}}$ & 1958,039729 \\
\hline
\end{tabular}

- Faktor keamanan keruntuhan daya dukung

$$
\begin{aligned}
F S_{\text {daya dukung }} & =\frac{q_{u}}{q_{\max }} \\
& =15,094
\end{aligned}
$$

Nilai resume faktor keamanan pada dinding kantilever dimensi baru beserta gaya yang bekerja pada dinding kantilever dimensi baru dapat dilihat pada Tabel 6. dan Gambar 11.

Tabel 6. Resume Faktor Keamanan Pada Dinding Kantilever Dimensi Baru

\begin{tabular}{|l|l|l|}
\hline Fs Guling & 3,547 & $>2$, oke \\
\hline Fs Geser & 2,559 & $>1,5$, oke \\
\hline $\begin{array}{l}\text { Fs Kapasitas daya } \\
\text { dukung }\end{array}$ & $\begin{array}{l}e=\frac{B}{2}-\frac{\Gamma_{1} M r-\Gamma_{\mathrm{a}} M_{0}}{\Sigma V} \\
\begin{array}{l}\text { Untuk mencari nilai Fs daya dukung, } \\
=14,676\end{array}\end{array}$ & $>3$, oke \\
\hline
\end{tabular}




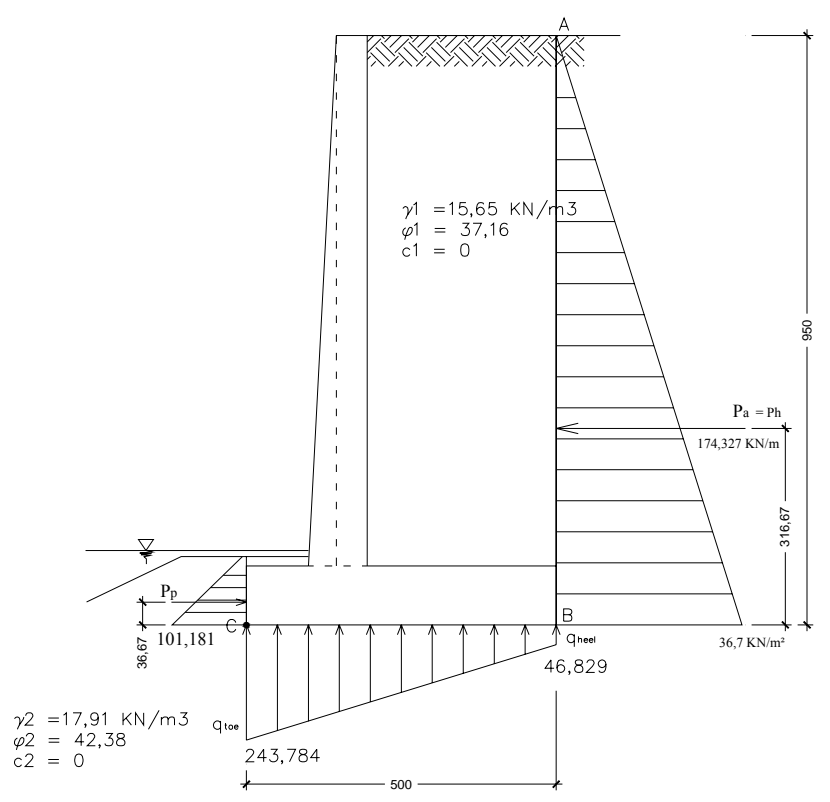

\section{Gambar 11. Gaya-Gaya yang Bekerja Pada Dinding Kantilever Dimensi Baru}

\subsubsection{Perhitungan Faktor Keamanan Terhadap Beban Dinamis}

Dalam perhitungan beban dinamis (Gambar 12 dan 13.), nilai percepatan puncak muka tanah a (g) untuk wilayah gempa 6 yang digunakan adalah sebesar 0,36 g berdasarkan SNI 0317262003 Perencanaan Ketahanan Gempa untuk Struktur Bangunan dan Gedung. a (g) merupakan percepatan dinamis maksimum.

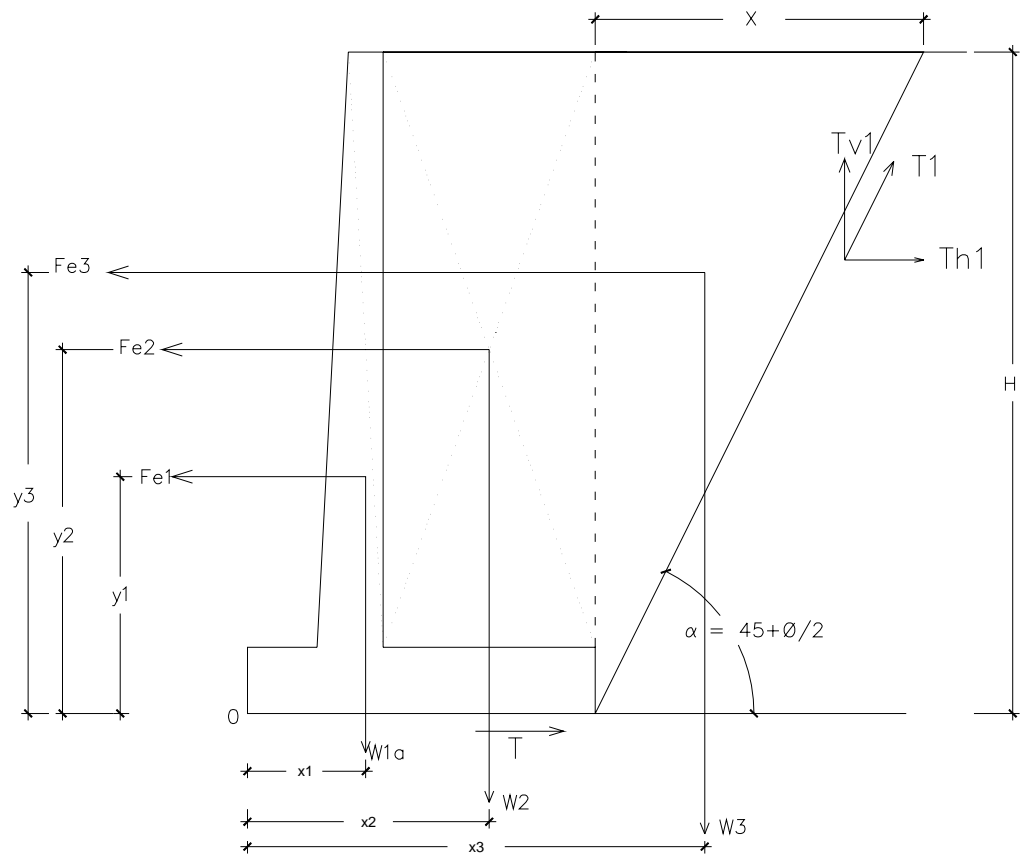

Gambar 12. Beban-Beban dan Gaya-Gaya yang Bekerja Akibat Beban Dinamis 


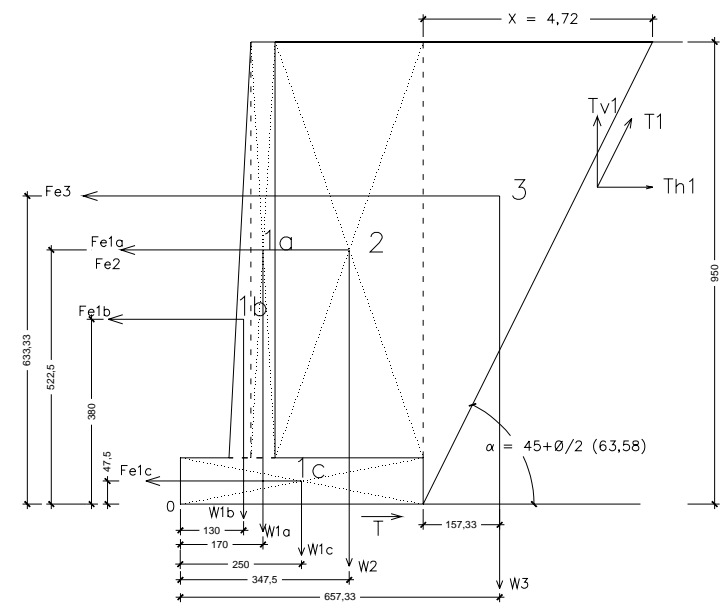

\section{Gambar 13. Analisis Dinamis Dinding Kantilever Dengan Dimensi Baru}

- Luas penampang masing-masing bagian yang dihitung

$$
\begin{aligned}
& \text { A1 }=4,3 \quad \mathrm{~m}^{2} \\
& \text { A1b }=1,9 \quad \mathrm{~m}^{2} \\
& \text { A1c }=4,8 \quad \mathrm{~m}^{2} \\
& \text { A2 }=26,1 \quad \mathrm{~m}^{2} \\
& \text { A3 }=22,42 \mathrm{~m}^{2}
\end{aligned}
$$

- Beban-beban dan gaya-gaya dinamis yang bekerja:

$$
\begin{aligned}
& \gamma_{\text {dinding }}=24 \mathrm{KN} / \mathrm{m}^{3} \\
& W_{1}=A_{1 a} \times \gamma_{\text {dinding }} \\
& =103,2 \frac{\mathrm{KN}}{\mathrm{m}} \\
& W_{2}=A_{1 b} \times \gamma_{\text {tanah }} \\
& =45,6 \frac{K N}{m} \\
& W_{3}=A_{1 \sigma} \times \gamma_{\text {tanah }} \\
& =115,2 \frac{\mathrm{kN}}{\mathrm{m}} \\
& F_{a 1 a}=W_{1 a} \times \frac{m_{g}}{g} \\
& =29,928 \frac{K N}{m} \\
& F_{91 b}=W_{1 b} \times \frac{\frac{m}{a_{g}}}{g} \\
& =13,224 \frac{\mathrm{KN}}{\mathrm{m}} \\
& F_{\theta 10}=W_{10} \times \frac{a_{g}}{g} \\
& =33,408 \quad \frac{K N}{m} \\
& F_{\theta 2}=W_{2} \times \frac{a_{g}}{\theta} \\
& =118,455 \quad \frac{\mathrm{kN}}{\mathrm{m}} \\
& F_{\mathrm{nR}}=W_{\mathrm{R}} \times \frac{a_{g}}{g} \\
& =101,753 \quad \frac{k N}{m}
\end{aligned}
$$




$$
\begin{aligned}
T_{1} & =W_{3} \times \sin \alpha \\
& =314,227 \quad \frac{\mathrm{KN}}{\mathrm{m}} \\
T_{v 1} & =W_{3} \times \sin ^{2} \alpha \\
& =261,406 \quad \frac{\mathrm{KN}}{\mathrm{m}} \\
T_{h 1} & =W_{3} \times \sin \alpha \times \cos \alpha \\
& =139,814 \quad \frac{\mathrm{KN}}{\mathrm{m}} \\
T= & c B+W_{1} \times \tan \varphi_{\text {dasar }} \\
& =613,615 \quad \frac{\mathrm{KN}}{\mathrm{m}}
\end{aligned}
$$

- Faktor Keamanan Guling

Resume beban-beban dan gaya-gaya yang bekerja akibat beban dinamis dapat dilihat pada Tabel 7.

Tabel 7. Resume Beban-Beban dan Gaya-Gaya yang Bekerja Akibat Beban Dinamis

\begin{tabular}{|r|c|c|c|c|c|}
\hline no & Beban & $\begin{array}{c}\text { Nilai Beban } \\
(\mathrm{KN})\end{array}$ & $\begin{array}{c}\text { Lengan Momen } \\
(\mathrm{m})\end{array}$ & $\begin{array}{c}\mathrm{M}_{0} \\
(\mathrm{KNm})\end{array}$ & $\begin{array}{c}\mathrm{M}_{\mathrm{R}} \\
(\mathrm{KNm})\end{array}$ \\
\hline \hline 1 & $\mathrm{~W}_{1 \mathrm{a}}$ & 103,2 & 1,7 & - & 175,44 \\
\hline 2 & $\mathrm{~W}_{1 \mathrm{~b}}$ & 45,600 & 1,3 & - & 59,28 \\
\hline 3 & $\mathrm{~W}_{1 \mathrm{c}}$ & 115,2 & 2,5 & - & 288 \\
\hline 2 & $\mathrm{~W}_{2}$ & 408,465 & 3,5 & - & 1429,6275 \\
\hline 3 & $\mathrm{~W}_{3}$ & 350,873 & 6,57 & - & 2305,23561 \\
\hline 4 & $\mathrm{Fe}_{1 \mathrm{a}}$ & 37,152 & 5,23 & 194,30496 & - \\
\hline 5 & $\mathrm{Fe}_{1 \mathrm{~b}}$ & 16,416 & 3,8 & 62,3808 & - \\
\hline 6 & $\mathrm{Fe}_{1 \mathrm{c}}$ & 41,472 & 0,48 & 19,90656 & - \\
\hline 5 & $\mathrm{Fe}_{2}$ & 147,047 & 5,2 & 764,6444 & - \\
\hline 6 & $\mathrm{Fe}_{3}$ & 126,314 & 6,3 & 795,7782 & - \\
\hline$\Sigma \mathrm{V}=\mathrm{W}_{1}+\mathrm{W}_{2}$ & 672,465 & $\Sigma$ & 1837,01492 & 4257,58311 \\
\hline
\end{tabular}

$$
\begin{aligned}
F S_{\text {guling }} & =\frac{\sum M_{R}}{\sum M_{0}} \\
& =2318
\end{aligned}
$$

- Faktor keamanan geser

$$
\begin{aligned}
K_{p} & =\tan ^{2}\left(45+\frac{\phi_{2}}{2}\right) \\
& =5,136 \\
P_{p} & =\frac{1}{2} \gamma_{2} H^{2} K_{p} \\
& =55,649 \frac{K N}{m} \\
P_{p} & =\frac{1}{2} \gamma_{p} H^{2} K_{p}
\end{aligned}
$$

Gaya yang mengakibatkan geser

$$
T_{0}=F e_{1 a}+F e_{1 b}+F e_{10}+F e_{2}+F e_{3}
$$

Tanpa tahanan pasif:

$$
\begin{aligned}
\mathrm{TR}=\mathrm{T} & =613,615 \\
F S_{\text {geser }} & =\frac{T R}{T_{0}} \\
& =1,666
\end{aligned}
$$


Dengan tahanan pasif:

$$
\begin{aligned}
\mathrm{TR}=\mathrm{T} & +\mathrm{Pp} \\
F S_{\text {gezer }} & =\frac{T R}{T_{0}} \\
= & 1,817
\end{aligned}
$$

- Faktor keamanan keruntuhan daya dukung

$$
\begin{aligned}
& q_{\max }=\frac{\sum V}{B}+\frac{1}{12 B} \\
& =134,51 \\
& \text { Untuk }=42,38 \\
& \mathrm{Nc}=101,842 \\
& \mathrm{Nq}=90,5632 \\
& \mathrm{~N} \gamma=167,3262
\end{aligned}
$$

Faktor-faktor daya dukung

$$
\begin{aligned}
& q=\gamma_{2} D \\
& =19,701 \frac{\mathrm{kN}}{\mathrm{m}^{\mathrm{N}}} \\
& B^{\prime}-B-2 e \\
& =0,343 \mathrm{~m} \\
& F_{\text {od }}=1+0,4 \frac{D}{D} \\
& =2,283 \\
& F_{\gamma d}=1 \\
& F_{\mathrm{q} d}=1+2 \tan \phi_{2}\left(1-\sin \phi_{2}\right)^{2} \frac{D}{B^{\prime}} \\
& =1,622 \\
& \psi^{0}=\tan ^{-1}\left[\frac{P_{a} \cos \alpha}{\Sigma V}\right] \\
& =14,029 \\
& F_{a i}=F_{q i}=\left[1-\frac{\psi^{0}}{90^{0}}\right]^{2} \\
& =0,713 \\
& F_{\gamma i}=\left[1-\frac{\psi^{0}}{\phi^{0}}\right]^{2} \\
& =0,447
\end{aligned}
$$

Karena nilai $\mathrm{c}=0$, maka rumus daya dukung ultimit menjadi:

$$
\begin{aligned}
q_{u} & =q N_{q} F_{q d} F_{q i}+\frac{1}{2} \gamma_{2} B^{\prime} N_{\gamma} F_{\gamma d} F_{\gamma i} \\
& =2,292 \times 10^{3} \frac{\mathrm{KN}}{\mathrm{m}^{2}}
\end{aligned}
$$

Nilai keamanan terhadap keruntuhan daya dukung

$$
\begin{aligned}
F S_{\text {daya dukung }} & =\frac{q_{u}}{q_{\max }} \\
& =17,038
\end{aligned}
$$

Perbandingan antara faktor keamanan yang diperoleh dari hasil analisa dan syarat yang diizinkan dapat dilihat pada Tabel 8. 
Tabel 8. Resume Faktor Keamanan Akibat Beban Dinamis

\begin{tabular}{|l|l|l|}
\hline Fs Guling & 2,318 & $>2$, oke \\
\hline Fs Geser & 1,666 & $>1,5$, oke \\
\hline $\begin{array}{l}\text { Fs } \\
\text { dayadukung }\end{array}$ & 17,038 & $>3$, oke \\
\hline
\end{tabular}

\subsubsection{Perhitungan Faktor Keamanan Terhadap Stabilitas Menyeluruh (Over-all Stability)}

Perhitungan over-all stability dilakukan dengan menggunakan metoda slices (Tabel 9.). Dalam metoda ini, garis keruntuhan diambil dengan memperkirakan bentuk keruntuhan tersebut dengan sebuah lingkaran berdiameter bebas. Lereng dibagi menjadi beberapa segmen dengan ukuran lebar segmen yang sama. Berikut adalah gambar dan perhitungan stabilitas menyeluruh dengan menggunakan metoda slices.

Nilai faktor stabilitas menyeluruh dari kondisi lereng tersebut adalah:

$$
\begin{aligned}
F S & =\frac{\Sigma(c L+W \cos \theta \tan \varphi)}{\sum W \sin \theta} \\
& =9,053
\end{aligned}
$$

\subsubsection{Perencanaan Tulangan Dinding Kantilever}

Gaya tekan aktif tanah timbunan

$$
\begin{aligned}
P_{1} & =\frac{1}{2} \gamma\left(\frac{1}{2} h^{2}\right) \mathrm{Ka} \\
& =70,6453 \mathrm{KN}
\end{aligned}
$$

\begin{tabular}{|c|c|c|c|c|c|c|c|c|c|c|c|c|c|c|}
\hline \multirow{2}{*}{ No } & A & $\gamma$ & W & $\theta$ & & $\sin \theta$ & $\cos \theta$ & $\tan$ & c & \multirow{2}{*}{$\begin{array}{c}\mathrm{L} \\
(10) \\
\end{array}$} & \multirow{2}{*}{$\begin{array}{c}\mathrm{CL} \\
(11) \\
\end{array}$} & \multirow{2}{*}{$\begin{array}{l}W \cos \theta \tan \\
12(3 \times 7 \times 8)\end{array}$} & \multirow{2}{*}{$\begin{array}{l}W \sin \theta \\
13(3 \times 6)\end{array}$} & \multirow{2}{*}{$\begin{array}{c}\mathrm{cL}+\mathrm{W} \cos \theta \tan \\
12(11+12) \\
\end{array}$} \\
\hline & (1) & $(2)$ & $3(1 \times 2)$ & (4) & (5) & $(6)$ & (7) & (8) & (9) & & & & & \\
\hline 1 & 4,226 & 15,65 & 66,1369 & 76 & 37,16 & 0,97029573 & 0,2419219 & 0,75794154 & 0 & 5,29 & 0 & 12,12703751 & 37,4406042 & 12,12703751 \\
\hline 2 & 7,77 & 15,65 & 121,6005 & 58 & 37,16 & 0,8480481 & 0,52991926 & 0,75794154 & 0 & 2,37 & 0 & 48,84057611 & 120,73381 & 48,84057611 \\
\hline 3 & 9,925 & 15,65 & 155,32625 & 48 & 37,16 & 0,74314483 & 0,66913061 & 0,75794154 & 0 & 1,88 & 0 & 78,77555329 & $-119,33012$ & 78,77555329 \\
\hline 4 & 11,457 & 15,65 & 179,30205 & 39 & 37,16 & 0,62932039 & 0,77714596 & 0,75794154 & 0 & 1,63 & 0 & 105,6145029 & \begin{tabular}{|l|}
172,810489 \\
\end{tabular} & 105,6145029 \\
\hline 5 & & & 209,05761 & 32 & 42,38 & 0,52991926 & 0,8480481 & 0,91248557 & 0 & 1,48 & 0 & 161,775395 & 115,279944 & 161,775395 \\
\hline 6 & & & 209,28083 & 25 & 42,38 & 0,42261826 & 0,90630779 & 0,91248557 & 0 & 1,39 & 0 & 173,0737345 & \begin{tabular}{|c|}
$-27,698684$ \\
\end{tabular} & 173,0737345 \\
\hline 7 & & & 254,3588 & 18 & 42,38 & 0,30901699 & 0,95105652 & 0,91248557 & 0 & 1,33 & 0 & 220,7390135 & $\mid-191,02021$ & 220,7390135 \\
\hline 8 & & & 67,28592 & 12 & 42,38 & 0,20791169 & 0,9781476 & 0,91248557 & 0 & 1,29 & 0 & 60,05574975 & \begin{tabular}{|l|}
$-36,103802$ \\
\end{tabular} & 60,05574975 \\
\hline 9 & 2,765 & 19,91 & 55,05115 & 6 & 42,38 & 0,10452846 & 0,9945219 & 0,91248557 & 0 & 1,27 & 0 & 49,95819616 & $-15,382145$ & 49,95819616 \\
\hline 10 & 2,845 & 19,91 & 56,64395 & 0 & 42,38 & 0 & $e_{0}$ & 0,91248557 & 0 & 1,26 & 0 & 51,68678689 & \begin{tabular}{|r|}
0 \\
\end{tabular} & 51,68678689 \\
\hline 11 & 2,754 & 19,91 & 54,83214 & -6 & 42,38 & $-0,1045285$ & 0,9945219 & 0,91248557 & 0 & 1,27 & 0 & 49,75944746 & 15,3209497 & 49,75944746 \\
\hline 12 & 2,49 & \begin{tabular}{|l|l|}
19,91 \\
\end{tabular} & 49,5759 & -12 & 42,38 & $-0,2079117$ & 0,9781476 & 0,91248557 & 0 & 1,29 & 0 & 44,24874987 & \begin{tabular}{|l|}
26,6010853 \\
\end{tabular} & 44,24874987 \\
\hline 13 & 2,042 & 19,91 & 40,65622 & -29 & 42,38 & $-0,4848096$ & 0,87461971 & 0,91248557 & 0 & 1,34 & 0 & 32,44682906 & 26,9808452 & 32,44682906 \\
\hline 14 & 1,39 & 19,91 & 27,6749 & -25 & 42,38 & $-0,4226183$ & 0,90630779 & 0,91248557 & 0 & 1,4 & 0 & 22,88694237 & 3,66282145 & 22,88694237 \\
\hline 15 & 0,51 & 19,91 & 10,1541 & -32 & 42,38 & $-0,5299193$ & 0,8480481 & 0,91248557 & 0 & 1,5 & 0 & 7,857563944 & \begin{tabular}{|l|}
$-5,5992417$ \\
\end{tabular} & 7,857563944 \\
\hline & & & & & & & & & & & & $\Sigma$ & 123,696346 & 1119,846078 \\
\hline
\end{tabular}

Tabel 9. Perhitungan Stabilitas Menyeluruh dengan Menggunakan Metode Slice

\begin{tabular}{|c|r|r|r|}
\hline No & \multicolumn{1}{|c|}{$A$} & \multicolumn{1}{c|}{$\gamma$} & \multicolumn{1}{c|}{ W } \\
\hline \hline $5 a$ & 10,86 & 15,65 & 169,959 \\
\hline $5 b$ & 1,203 & 24 & 28,872 \\
\hline $5 c$ & 0,571 & 17,91 & 10,22661 \\
\hline $6 a$ & 9,925 & 15,65 & 155,32625 \\
\hline $6 b$ & 1,175 & 24 & 28,2 \\
\hline $6 c$ & 1,438 & 17,91 & 25,75458 \\
\hline $7 a$ & 2,527 & 15,65 & 39,54755 \\
\hline $7 b$ & 7,402 & 24 & 177,648 \\
\hline $7 c$ & 2,075 & 17,91 & 37,16325 \\
\hline $8 a$ & 0,929 & 24 & 22,296 \\
\hline $8 b$ & 2,512 & 17,91 & 44,98992 \\
\hline
\end{tabular}


Garis kerja $\mathrm{P}_{1}$ dari dasar dinding:

$$
\begin{aligned}
y_{1} & =\frac{1}{3} h_{1} \\
& =1,425 \mathrm{~m} \\
P_{a} & =\frac{1}{2} \gamma\left(h^{2}\right) \mathrm{Ka} \\
& =141,29 \mathrm{KN}
\end{aligned}
$$

Garis kerja $\mathrm{P}_{\mathrm{a}}$ dari dasar dinding:

$$
\begin{aligned}
y_{a} & =\frac{1}{3} H \\
& =2,85 \mathrm{~m}
\end{aligned}
$$

Gaya berat sendiri dinding dan tanah

$$
\begin{aligned}
W_{c} & =\gamma_{c}\left(B_{1}\right) T_{2} \quad \text { (berat tapak belakang, bentuk persegi) } \\
& =69,54 \\
W_{s} & =\gamma_{1} B_{1}\left(H-T_{2}\right) \\
=408,113 \mathrm{KN} & \\
W & =W_{s}+W_{s} \\
& =477,653 \mathrm{KN}
\end{aligned}
$$

Garis kerja titik tapak belakang:

$$
\begin{aligned}
\mathrm{x}_{1} & =1 / 2 \mathrm{~B}_{1} \\
& =1.525 \mathrm{~m}
\end{aligned}
$$

Garis kerja titik tapak depan:

$$
\begin{aligned}
\mathrm{x}_{2} & =1 / 2 \mathrm{~B}_{1}+\mathrm{T}_{1} \\
& =2.475 \mathrm{~m}
\end{aligned}
$$

Untuk badan dinding tegak:

$$
\begin{aligned}
\mathrm{W}_{\mathrm{t}} & =\gamma_{\mathrm{c}} \cdot \mathrm{T}_{1}\left(\mathrm{H}-\mathrm{T}_{2}\right) \\
& =194.94 \mathrm{KN}
\end{aligned}
$$

Garis kerja terhadap titik kaki depan:

$$
\begin{aligned}
\mathrm{x}_{\mathrm{t}} & =1 / 2 \mathrm{~T} \\
& =0.475 \mathrm{~m}
\end{aligned}
$$

Momen Pada Dinding (Gambar 14.)

$$
\begin{aligned}
& \mathrm{M}_{\mathrm{f}} \quad=\mathrm{P} \cdot \mathrm{y}_{\mathrm{l}} \\
& =100.669 \quad \text { KN.m } \\
& \mathrm{M}_{\mathrm{b}} \quad=\mathrm{P}_{\mathrm{a}} \cdot \mathrm{y}_{\mathrm{a}} \\
& =402.676 \quad \mathrm{KN} \cdot \mathrm{m} \\
& \mathrm{M}_{\mathrm{h}} \quad=\mathrm{W} \cdot \mathrm{x}_{1} \\
& =728.42 \quad \text { KN.m } \\
& \mathrm{M}_{\mathrm{t}}=\mathrm{W} \cdot \mathrm{x}_{2}+\mathrm{Wt} \cdot \mathrm{x}_{\mathrm{t}} \\
& =1274,7876 \quad \mathrm{KN} \cdot \mathrm{m}
\end{aligned}
$$

Gaya Geser Pada Dinding

$$
\begin{aligned}
\mathrm{T}_{\mathrm{f}} & =\mathrm{P}_{1} \\
& =70,6453 \mathrm{KN} \\
\mathrm{T}_{\mathrm{b}} & =\mathrm{P}_{\mathrm{a}}
\end{aligned}
$$




$$
\begin{aligned}
& =141,29 \mathrm{KN} \\
\mathrm{T}_{\mathrm{h}} & =\mathrm{W} \\
& =477,653 \mathrm{KN} \\
\mathrm{T}_{\mathrm{t}} & =\mathrm{W}+\mathrm{W}_{\mathrm{t}} \\
& =672,59 \mathrm{KN}
\end{aligned}
$$

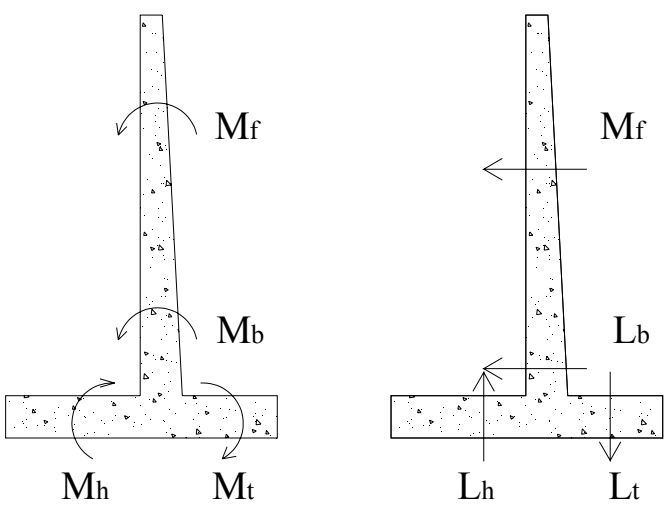

\section{Gambar 14. Momen dan Lintang Pada Dinding Kantilever}

\section{Menentukan perkuatan/ tulangan akibat Momen}

Untuk menentukan perkuatan ini digunakan grafik kebutuhan tulangan tarik terhadap momen lentur per meter untuk mutu beton K-225 s/d K-300 (Gambar 15.).

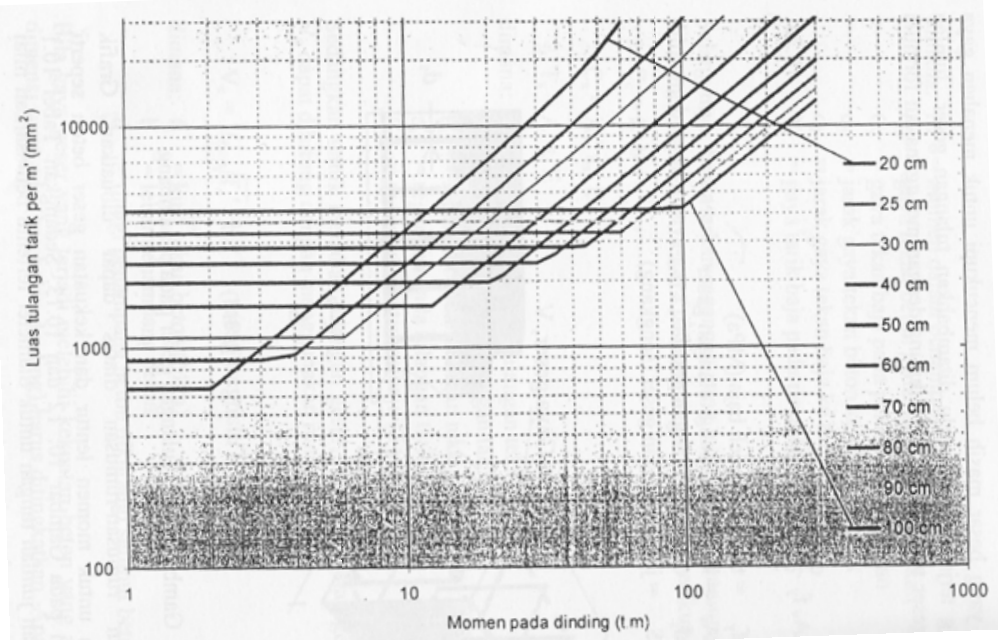

Gambar 15. Kebutuhan Tulangan Tarik Terhadap Momen Lentur Per Meter Untuk Mutu Beton K-225 s/d K-300

Jika nilai momen yang bekerja pada dinding diplot pada grafik, maka akan diperoleh luas tulangan tarik per m' adalah (Tabel 10. dan Gambar 17.):

1. Mf diperlukan luas tulangan minimum $2500 \mathrm{~mm}^{2}$

2. $\mathrm{Mb}$ diperlukan luas tulangan minimum $2500 \mathrm{~mm}^{2}$

3. Mh diperlukan luas tulangan minimum $2500 \mathrm{~mm}^{2}$

4. Mt diperlukan luas tulangan minimum $10500 \mathrm{~mm}^{2}$

\section{2 | JURNAL REKAYASA SIPIL}


Tabel 10. Luas Penampang Vs Jumlah Tulangan Lentur

\begin{tabular}{|c|c|c|c|c|c|}
\hline \multirow{2}{*}{$\begin{array}{c}\text { Luas As } \\
\left(\mathrm{mm}^{2}\right)\end{array}$} & \multicolumn{5}{|c|}{ Jumlah Tulangan Lentur } \\
\cline { 2 - 6 } & $\mathrm{D}-12$ & $\mathrm{D}-16$ & $\mathrm{D}-19$ & $\mathrm{D}-22$ & $\mathrm{D}-25$ \\
\hline 600 & 6 & 3 & 3 & 2 & 2 \\
\hline 650 & 6 & 4 & 3 & 2 & 2 \\
\hline 700 & 7 & 4 & 3 & 2 & 2 \\
\hline 800 & 8 & 4 & 3 & 3 & 2 \\
\hline 900 & 8 & 5 & 4 & 3 & 2 \\
\hline 1000 & 9 & 5 & 4 & 3 & 3 \\
\hline 1200 & 11 & 6 & 5 & 4 & 3 \\
\hline 1400 & 13 & 7 & 5 & 4 & 3 \\
\hline 1600 & 15 & 8 & 6 & 5 & 4 \\
\hline 1800 & 16 & 9 & 7 & 5 & 4 \\
\hline 2000 & 18 & 10 & 8 & 6 & 5 \\
\hline 2500 & 23 & 13 & 9 & 7 & 6 \\
\hline 3000 & 27 & 15 & 11 & 8 & 7 \\
\hline 3500 & 31 & 18 & 13 & 10 & 8 \\
\hline 4000 & 36 & 20 & 15 & 11 & 9 \\
\hline 5000 & 45 & 25 & 18 & 14 & 11 \\
\hline 6000 & 54 & 30 & 22 & 16 & 13 \\
\hline 7000 & 62 & 35 & 25 & 19 & 15 \\
\hline 8000 & 71 & 40 & 29 & 22 & 17 \\
\hline 9000 & 80 & 45 & 32 & 24 & 19 \\
\hline 10000 & 89 & 50 & 36 & 27 & 21 \\
\hline 15000 & 133 & 75 & 53 & 40 & 31 \\
\hline 20000 & 177 & 100 & 71 & 53 & 41 \\
\hline 25000 & 222 & 125 & 89 & 66 & 51 \\
\hline 30000 & 266 & 150 & 106 & 79 & 62 \\
\hline & & & & & \\
\hline
\end{tabular}

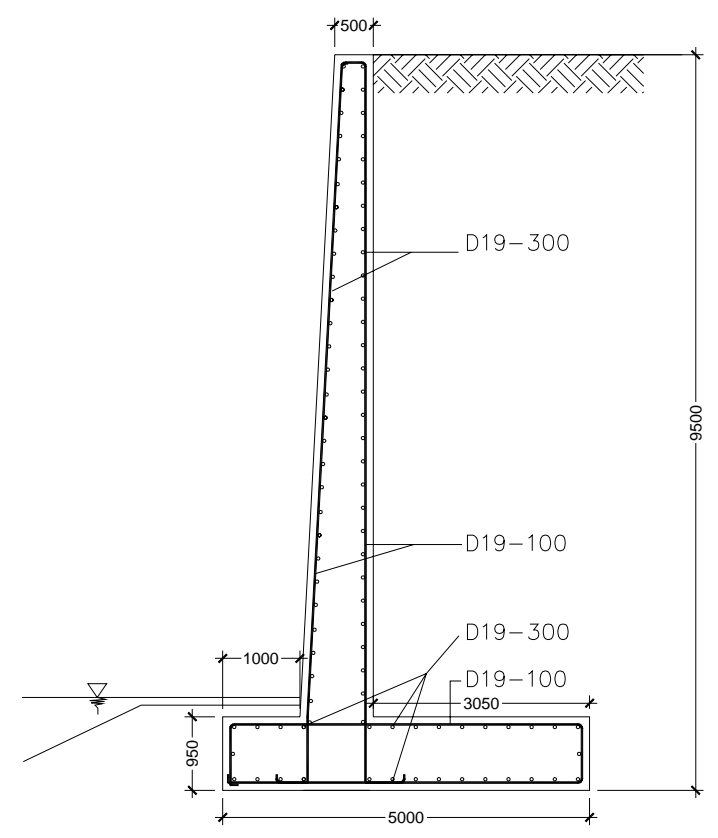

Gambar 16. Gambar Tulangan Dinding Kantilever

\section{KESIMPULAN}

Berdasarkan hasil analisis dan perhitungan yang dilakukan maka didapatkan kesimpulan sebagai berikut:

1. Berdasarkan hasil perhitungan stabilitas, nilai faktor keamanan dinding kantilever dengan kondisi tidak aman terhadap daya dukung dan penggerusan. 
2. Nilai stabilitas dinding penahan tanah dengan kondisi asli adalah Fs Overtuning 1,577, nilai Fs Sliding 1,384 dan nilai Fs Bearring capacity tidak dapat diperoleh hasil, karena nilai e $>$ B/6.

3. Dinding penahan tanah dengan dimensi yang baru aman terhadap dayadukung dan penggerusan

4. Berdasarkan hasil perhitungan stabilitas dinding kantilever dengan dimensi yang baru diperoleh nilai Fs Overtuning 3,547, nilai Fs Sliding 2,559 dan nilai Fs Bearring capacity 14,676.

5. Nilai penggerusan (scouring) pada dasar dinding kantilever adalah $1,02 \mathrm{~m}$.

6. Nilai stabilitas menyeluruh dinding kantilever dengan dimensi baru diperoleh sebesar 9,053

7. Perencanaan tulangan diperoleh jumlah tulangan minimum dinding tegak 9 D 19 dan dasar dinding $36 \mathrm{D} 19$.

\section{DAFTAR KEPUSTAKAAN}

Bowles, Joseph (translated by Sinaban Pantur), (1999), “Analisis dan Disain Pondasi” edisi ke tiga jilid 2. Jakarta. Penerbit Erlangga

Das, Braja M (translated by Mochtar. N. E and Mochtar I.B.), (1995), "Mekanika Tanah (Prinsipprinsip Rekayasa Geoteknis)” Jilid 2, Jakarta, Penerbit Erlangga.

Das, Braja M, (1990), "Principles Of Foundation Engineering, second edition", Boston, PWSKENT Publishing Company. 